\title{
A Study of Incidence and Microbiological Profile of Ventilator Associated Tracheobronchitis (VAT) in a Tertiary Care Hospital
}

\author{
P. Nanthini Devi ${ }^{1^{*}}$ and S. Gomathi ${ }^{2}$ \\ ${ }^{1}$ Department of Microbiology, Sree Balaji Medical College and Hospital, Chennai, \\ Tamil Nadu, India \\ ${ }^{2}$ Department of Microbiology, SRM Medical College Hospital and Research Centre, \\ Kattankulathur, Tamil Nadu, India \\ *Corresponding author
}

\begin{tabular}{|l|}
\hline Ke y w o r d s \\
$\begin{array}{l}\text { Ventilator associated } \\
\text { tracheobronchitis, } \\
\text { Ventilator associated } \\
\text { pneumonia, Multi drug } \\
\text { resistance }\end{array}$ \\
\hline Article Info \\
\hline $\begin{array}{l}\text { Accepted: } \\
\text { 07 March } 2018 \\
\text { Available Online: } \\
\text { 10 April 2018 }\end{array}$ \\
\hline
\end{tabular}

\section{Introduction}

Ventilator associated respiratory infections are the most common infections in persons receiving mechanical ventilation. Ventilator associated tracheobronchitis (VAT) and Ventilator associated pneumonia (VAP) occur 48 hours after the onset of mechanical ventilation. The prevalence varies from 1.4-

\begin{abstract}
Ventilator-associated tracheobronchitis (VAT) is a common intensive care unit (ICU)acquired infection. Its incidence ranges from 1.4 to $19 \%$ of critically ill patients receiving invasive mechanical ventilation. This infection is considered as an intermediate process between between colonization and ventilator-associated pneumonia (VAP). 1. To study the incidence of VAT. 2. To study the microbiological profile and anti-microbial susceptibility. This is a prospective study of 149 intubated patients. The endotracheal aspirates were collected and processed. VAT was diagnosed on microbiological and clinical basis. All the relevant clinical details were recorded. An incidence of $24.83 \%$ of VAT cases was recorded with male predominance. Various underlying conditions like Cerebrovascular accident, Coronary artery disease, Chronic kidney disease were found to be associated with VAT. Most of them had comorbidities such as hypertension and diabetes mellitus. Acinetobacter baumannii (33.33\%), Klebsiella pneumoniae (22.22\%), Candida albicans (13.33\%) and Staphylococcus aureus (11.11\%) were the most frequently encountered pathogens in patients with VAT. The mortality was found to be $18.92 \%$. Patients with VAT experienced longer ICU stay and more prolonged mechanical ventilation compared to patients without VAT. Formulation of a good infection control policy and emphasis on health education will prevent the transmission of multidrugresistant organisms in the Intensive care units.
\end{abstract}


moderate to heavy growth by semi quantitative method $\left(>10^{5} \mathrm{CFU} / \mathrm{ml}\right.$ and the absence of chest radiographic findings (Martin-Loeches et al., 2013). The incidence of VAP is increased in patients with VAT (Craven, 2008).

VAT can be caused by both Gram positive and Gram negative pathogens such as Pseudomonas aeruginosa, Staphylococcus aureus, Acinetobacter baumannii, Escherichia coli, Klebsiella pneumoniae. The most gruelling part is that these pathogens are multidrug resistant (Saad Nseir et al., 2008). VAT is associated with increased duration of mechanical ventilation, ICU stay and hospital costs (Nseir et al., 2005). Appropriate antibiotic therapy after serial culture and sensitivity of the tracheal secretions is needed to reduce the risk of progression of VAT to VAP (Craven et al., 2016).

Many studies have focused on the study of VAP. But there are very few articles regarding VAT. The current article emphasizes the incidence, microbiology, multidrug resistance in the pathogens which can be a guide to the treating physician.

\section{Materials and Methods}

This was a prospective study which was done for a period of one year in the ICU complex of a tertiary care hospital after obtaining Institutional ethical clearance.

\section{Inclusion criteria}

Patients who were admitted and underwent mechanical ventilation $>24$ hours in the age group $>18$ years

\section{Exclusion criteria}

Patients with respiratory problems on admission like COPD (Chronic obstructive pulmonary disease), tuberculosis, Asthma and ARDS (Acute respiratory distress syndrome).

\section{Materials and Methods}

The study was conducted in the ICU complex of a tertiary care hospital. A total of 149 patients on ventilator were included. The cases included both males and females more than 18 years who were on mechanical ventilation. All patients having respiratory system disorders like COPD, Asthma, Tuberculosis were excluded from the study.

A proforma was prepared and the relevant details like age, sex, diagnosis at the time of admission, indication and date of ventilation, ventilation mode and settings, antibiotics given, investigations done, chest X-ray findings, duration of ventilation, ICU stay and hospital stay were noted. The patient was monitored from the date of admission till the date of discharge and the outcome was noted.

The endotracheal aspirates were collected using a mucous extractor. The samples were transported to the laboratory with minimal delay and were processed immediately to prevent the overgrowth of bacterial pathogens.

A Gram stain was performed and the sample cultured on 5\% Sheep Blood agar, Chocolate agar and incubated at $35^{\circ} \mathrm{C}$ for 24 hours and on Sabouraud's dextrose agar at $24^{\circ} \mathrm{C}$ for 48 hours. The routine biochemical tests were performed and antimicrobial susceptibility testing done by Kirby Bauer method as per CLSI (Clinical and laboratory standards institute) guidelines.

\section{Antimicrobial susceptibility testing}

The purpose of the Kirby-Bauer disk diffusion susceptibility test was done to determine the sensitivity or resistance of pathogenic bacteria to various antimicrobial drugs. 
Inoculation of the Mueller Hinton agar plate

A lawn culture of the test bacteria was applied on the Mueller Hinton agar plate. The appropriate antimicrobial impregnated disks were placed on the surface of the agar using forceps and the lid was replaced and incubated at $35^{\circ} \mathrm{C}$ for $16-18$ hours.

Following incubation, the zone sizes were measured. Using the published CLSI guidelines, the susceptibility or resistance of the organism to each drug tested was noted.

The results of the Kirby-Bauer disk diffusion susceptibility test were reported only as susceptible, intermediate, or resistant.

\section{Antibiotics tested}

\section{Gram positive bacteria}

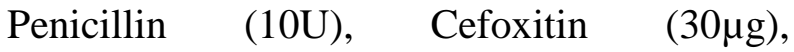
Gentamicin $(10 \mu \mathrm{g})$, Erythromycin $(15 \mu \mathrm{g})$, Clindamycin (2 $\mu \mathrm{g}), \quad$ Cotrimoxazole $(1.25 / 23.75 \mu \mathrm{g}), \quad$ Ciprofloxacin $(5 \mu \mathrm{g})$, Linezolid $(30 \mu \mathrm{g}), \quad$ Teicoplanin $(30 \mu \mathrm{g})$, Vancomycin $(30 \mu \mathrm{g})$

In the case of Enterococcus, Ampicillin (10 $\mu \mathrm{g})$, High level Gentamicin (120 $\mu \mathrm{g})$, Ciprofloxacin $(5 \mu \mathrm{g})$, Linezolid $(30 \mu \mathrm{g})$, Teicoplanin $(30 \mu \mathrm{g})$, Vancomycin $(30 \mu \mathrm{g})$ were used.

\section{Enterobacteriaceae}

Ampicillin $(10 \mu \mathrm{g})$, Ceftazidime $(30 \mu \mathrm{g})$, Ceftriaxone $(30 \mu \mathrm{g})$, Cefotaxime $(30 \mu \mathrm{g})$, Cefepime $(30 \mu \mathrm{g})$, Cefoperazone Sulbactam $(75 / 30 \mu \mathrm{g})$, Piperacillin Tazobactam (100/10 $\mu \mathrm{g})$, Amikacin $(30 \mu \mathrm{g})$, Ciprofloxacin $(5 \mu \mathrm{g})$, Cotrimoxazole $(1.25 / 23.75 \mu \mathrm{g})$,Imipenem $(10$ $\mu \mathrm{g})$, Meropenem $(10 \mu \mathrm{g})$, Tigecycline $(15 \mu \mathrm{g})$, Colistin $(10 \mu \mathrm{g})$.

\section{Pseudomonas}

Ceftazidime $(30 \mu \mathrm{g})$, Ceftriaxone $(30 \mu \mathrm{g})$, Cefepime $(30 \mu \mathrm{g})$, Cefoperazone Sulbactam $(75 / 30 \mu \mathrm{g})$, Piperacillin Tazobactam (100/10 $\mu \mathrm{g})$, Amikacin $(30 \mu \mathrm{g})$, Ciprofloxacin $(5 \mu \mathrm{g})$, Cotrimoxazole (1.25/23.75 $\mu \mathrm{g})$, Imipenem (10 $\mu \mathrm{g})$, Meropenem $(10 \mu \mathrm{g})$, Doripenem $(10 \mu \mathrm{g})$, Tigecycline $(15 \mu \mathrm{g})$, Colistin $(10 \mu \mathrm{g})$.

\section{Acinetobacter}

Ceftazidime $(30 \mu \mathrm{g})$, Ceftriaxone $(30 \mu \mathrm{g})$,

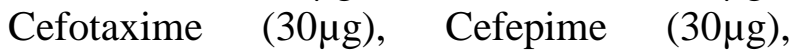
Cefoperazone Sulbactam (75/30 $\mu \mathrm{g})$, Piperacillin Tazobactam (100/10 $\mu \mathrm{g})$,

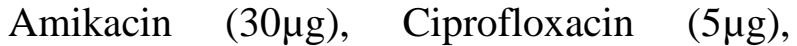
Cotrimoxazole $(1.25 / 23.75 \mu \mathrm{g})$, Imipenem $(10$ $\mu \mathrm{g})$, Meropenem $(10 \mu \mathrm{g})$, Tigecycline $(15 \mu \mathrm{g})$, Colistin $(10 \mu \mathrm{g})$.

\section{Results and Discussion}

The total number of patients in our study was 149 among which 37 (24.83\%) developed VAT and $30(20.13 \%)$ were colonisers of the respiratory tract.

Out of the149 patients, 101 (67.78\%) were males and $48(32.22 \%)$ were females. Males predominated the study (Fig. 1).

The maximum numbers of cases were seen in the age group of 41 to 60 years $(43.62 \%)$ followed by 61-80 years (37.58\%) (Fig. 2).

The most common reason for RICU admission in our hospital was Multisystem involvement (40.27\%), Central nervous system disorders $(25.51 \%)$ followed by Kidney diseases (14.09\%), Coronary artery disease (4.7\%) (Fig. 3).

Liver diseases (2.68\%) and miscellaneous causes which includes Road traffic accident, Snake bite, Poisoning and Undiagnosed fever $(12.75 \%)$. 
Among the 37 patients who developed VAT, $28(75.68 \%)$ were males and $9(24.32 \%)$ were females (Fig. 4).

$82.76 \%$ were ventilated for poor GCS (Glascow coma scale), 12. $07 \%$ for desaturation and $5.17 \%$ for airway protection (Fig. 5).

Among the 37 VAT patients, $51.35 \%$ were smokers, $40.54 \%$ were alcoholics, $5.41 \%$ were addicted to both alcohol and smoking and $2.7 \%$ did not smoke or consume alcohol (Fig. 6).

The maximum prevalence was seen in the age group of $41-60$ years $(40.54 \%)$ followed by $61-80$ years $(32.43 \%)$

$43.24 \%$ of VAT patients had multisystem disorders, $24.32 \%$ has kidney disorders, $18.92 \%$ had central nervous system disorders, $5.41 \%$ had cardiovascular system involvement and $8.11 \%$ were admitted with poisoning, road traffic accidents and carcinomas (Fig. 7).

$32.76 \%$ had hypertension, $25.86 \%$ had diabetes, $17.24 \%$ had both diabetes and hypertension and $24.14 \%$ had no co morbidities (Fig. 8).

$89.66 \%$ had one organism in endotracheal aspirate and $10.34 \%$ had two organisms (Fig. 9).

Acinetobacter baumannii was responsible for $33.33 \%$ of VAT infections followed by Klebsiella pneumoniae (22.22\%), Pseudomonas aeruginosa (8.89\%), Staphylococcus aureus (11.11\%), Candida albicans (13.33\%), Escherichia coli (4.44\%), Citrobacter, Enterococcus, Proteus each $2.22 \%$.

Ventilator associated tracheobronchitis is an important ventilator associated respiratory infection in the ICU. Its prevalence varies from $1.4 \%$ to $9 \%$ (Nseir and Martin-Loeches, 2014). It is an important cause of increased morbidity and mortality in hospitals. The present study was undertaken in the RICU complex of a tertiary care hospital. After excluding patients with respiratory system disorders on admission and patients who developed VAP, a total of 149 patients were allotted for the study out of which $67.78 \%$ were males and $32.22 \%$ were females. The maximum numbers of cases were seen in the age group of 41 to 60 years $(43.62 \%)$ followed by $61-80$ years $(37.58 \%)$.

The most common reason for RICU admission in our hospital was Multisystem involvement $(40.27 \%)$, Central nervous system disorders $(25.51 \%)$ followed by Kidney diseases (14.09\%), Coronary artery disease (4.7\%), Liver diseases $(2.68 \%)$ and miscellaneous causes which includes Road traffic accident, Snake bite, Poisoning and Undiagnosed fever $(12.75 \%)$.

The incidence of VAT in our study was $24.83 \%$. The incidence of VAT reported in other studies were $15 \%$ by Lei et al., and 13.2 $\%$ by Ray et al., which is lower compared to our study. The increased prevalence in our study may be due to the increased number of patients who were admitted with multisystem disorders and infection with virulent and multi drug resistant pathogens,

Among the 37 patients who developed VAT, $28(75.68 \%)$ were males and $9(24.32 \%)$ were females. This is in contrast to the study by Dallas et al., in which $50 \%$ were males and $50 \%$ were females but similar to Ray et al., who reported $75 \%$ of males and $25 \%$ of females (Dallas et al., 2011).

$82.76 \%$ of patients were ventilated for poor GCS, $12.07 \%$ for desaturation and $5.17 \%$ for airway protection. $32.76 \%$ had hypertension, $25.86 \%$ had diabetes, $17.24 \%$ had both diabetes and hypertension and $24.14 \%$ had no 
co morbidities. Mayuri et al., reported $37.2 \%$ of patients with diabetes and $30 \%$ of patients with hypertension (Mayuri, 2017). Sadek et al., reported $20 \%$ of diabetics and $40 \%$ of hypertension patients in VAT patients (Sadek et al., 2014).

Among the 37 VAT patients, $51.35 \%$ were smokers, $40.54 \%$ were alcoholics, $5.41 \%$ were addicted to both alcohol and smoking and $2.7 \%$ did not smoke or consume alcohol.

The increased incidence $(40.54 \%)$ was seen in the age group of 41-60 years followed by 6180 years $(32.43 \%)$

Hashemi et al., in their study identified $33 \%$ in the $70-89$ years, $26 \%$ in the 50-69 years age group followed by $24.6 \%$ in $30-49$ years which is different from our study (Hashemi et al., 2017).

But Mayuri et al., in their study reported $18 \%$ of patients in the age group of 41-50 years and $13 \%$ in the $50-60$ years age group which is similar to our study (Mayuri, 2017).

$43.24 \%$ of VAT patients had multisystem disorders, $24.32 \%$ has kidney disorders, $18.92 \%$ had central nervous system disorders, $5.41 \%$ had cardiovascular system involvement and $8.11 \%$ were admitted with poisoning, road traffic accidents and carcinomas. Nseir et al., in their study reported $21 \%$ of patients with central nervous system disorders and $25 \%$ of patients with kidney disorders and $20 \%$ of patients with cardiac problems (Nseir et al., 2005).

$89.66 \%$ of isolates were monomicrobial and $10.34 \%$ of isolates were polymicrobial yielding a total of 68 isolates. This is in controversy to the study by Sadek et al., who reported $40 \%$ of polymicrobial VAT and the causative organisms were Acinetobacter and Pseudomonas (40\%) (Sadek et al., 2014). Gram negative pathogens were responsible for
$75.54 \%$ of VAT infections followed by $13.33 \%$ of Gram positive bacteria. Karvouniaris et al., reported $92.9 \%$ of VAT caused by Gram negative bacteria (Karvouniaris et al., 2013). Acinetobacter baumannii was responsible for $33.33 \%$ of VAT infections followed by Klebsiella pneumoniae (22.22\%), Staphylococcus aureus (11.11\%), Pseudomonas aeruginosa (8.89\%), Escherichia coli (4.44 \%), Citrobacter, Enterococcus, Proteus each 2.22\%. Candida albicans was responsible for $13.33 \%$ of VAT infections.

The most common pathogen of VAT was Pseudomonas aeruginosa $52.3 \%$ followed by Klebsiella pneumoniae $20.8 \%$ in a similar study by (Babu et al., 2011).

In a study by Mayuri et al., Pseudomonas aeruginosa was the predominant pathogen isolated (29\%) followed by Klebsiella pneumoniae (26\%), Acinetobacter baumannii (20\%), Staphylococcus aureus (12\%), Escherichia coli (8\%) and Citrobacter freundii (6\%) (Mayuri, 2017).

In a study by Dallas et al., Gram negative bacteria $(50 \%)$ were the predominant causative organisms of VAT when compared to Gram positive bacteria ( $37.5 \%)$.

MRSA was the predominant bacteria (18.8\%) followed by Acinetobacter baumannii (15.6\%), Pseudomonas aeruginosa (9.4\%) (Dallas et al., 2011).

Acinetobacter baumannii was responsible for $33.33 \%$ of cases with VAT.

It is a virulent bacteria and very resistant to adverse conditions and is an emerging pathogen of nosocomial infections, particularly patients admitted in the ICU and on mechanical ventilation (Manchanda et al., 2010) (Table 1-5). 
Fig.1 Gender distribution of the study group

\section{GENDER DISTRIBUTION OF THE STUDY GROUP}

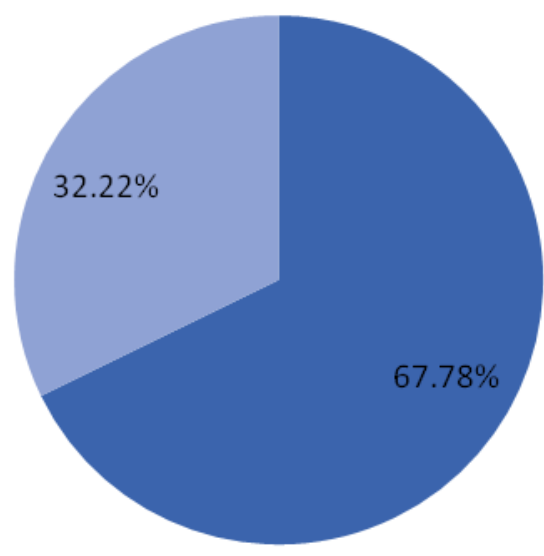

Fig.2 Age distribution of the study group

\section{ÁGE DISTRÍUUTION OF THE STUDY GROUP}

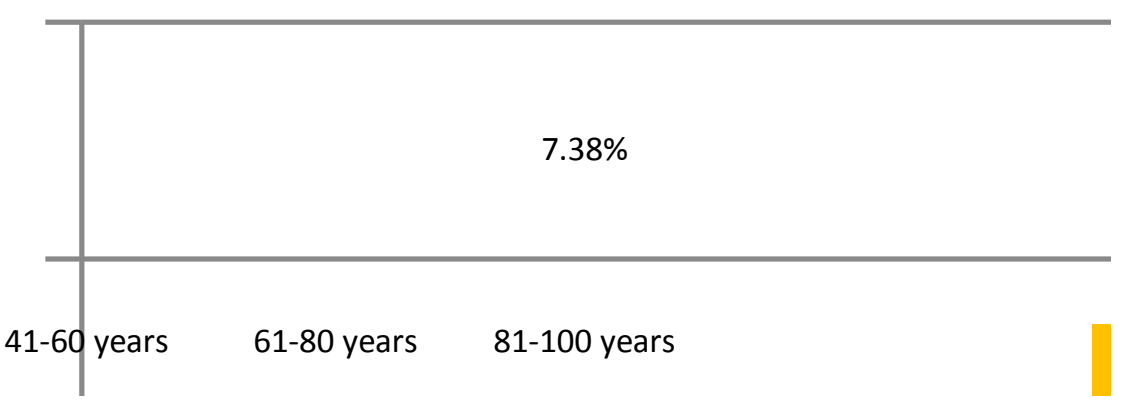


Fig.3 Distribution of study group by diagnosis

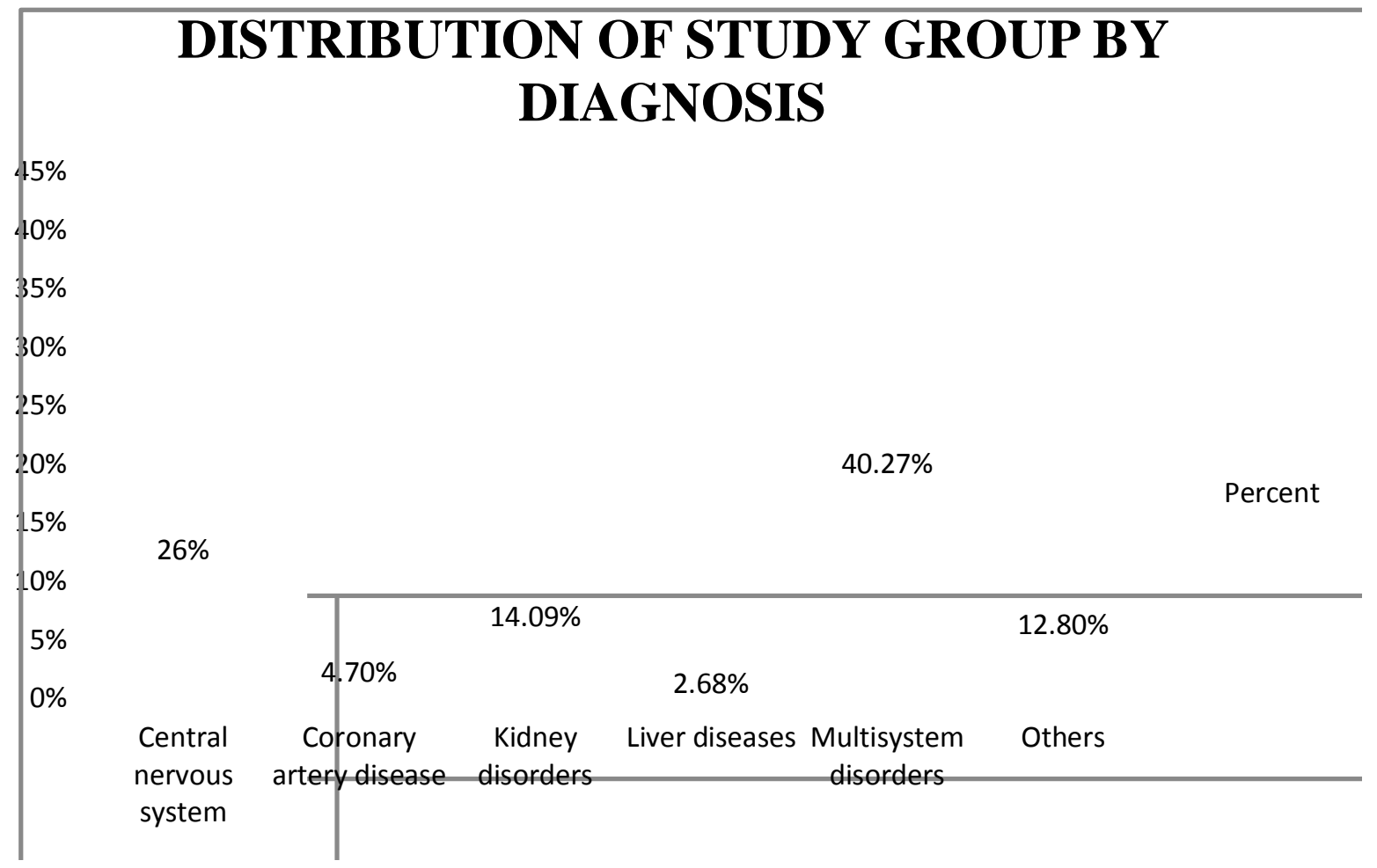

Fig.4 Gender distribution of VAT patients

\section{GENDER DISTRIBUTION OF VAT PATIENTS}

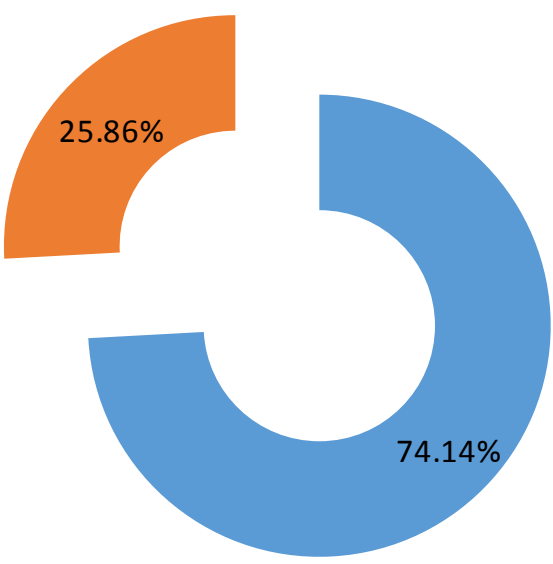

Males

Females 
Fig.5 Indications for ventilation in VAT patients

\section{INDICATIONS FOR VENTILATION}

$5 \%$

$12 \%$

Airway protection

Desaturation

Poor GCS

$83 \%$

Fig.6 Distribution of VAT patients by personal habits

\section{DISTRIBUTION OF VAT PATIENTS BY PERSONAL HABITS}

$5.41 \% 2.70 \%$

\begin{tabular}{|c|c|c|}
\hline & & Smoker \\
\hline & & Alcoholic \\
\hline $40.54 \%$ & $51.35 \%$ & Alcoholic and smoker \\
\hline & & Nil \\
\hline
\end{tabular}


Fig.7 Distribution of VAT patients by diagnosis

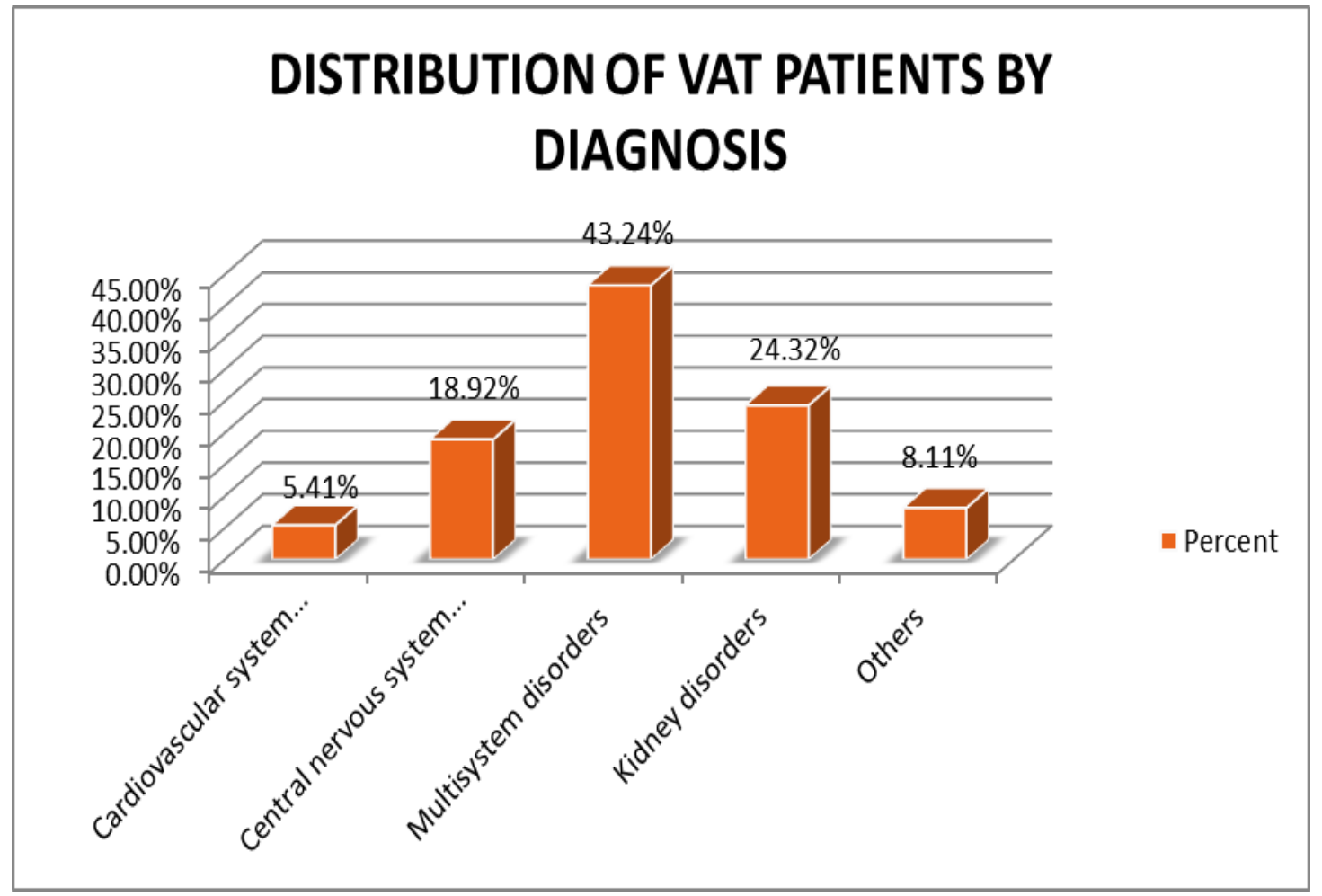

Fig.8 Distribution of VAT patients by co morbidities

\section{DISTRIBUTION OF VAT PATIENTS BY CO MORBIDITIES}

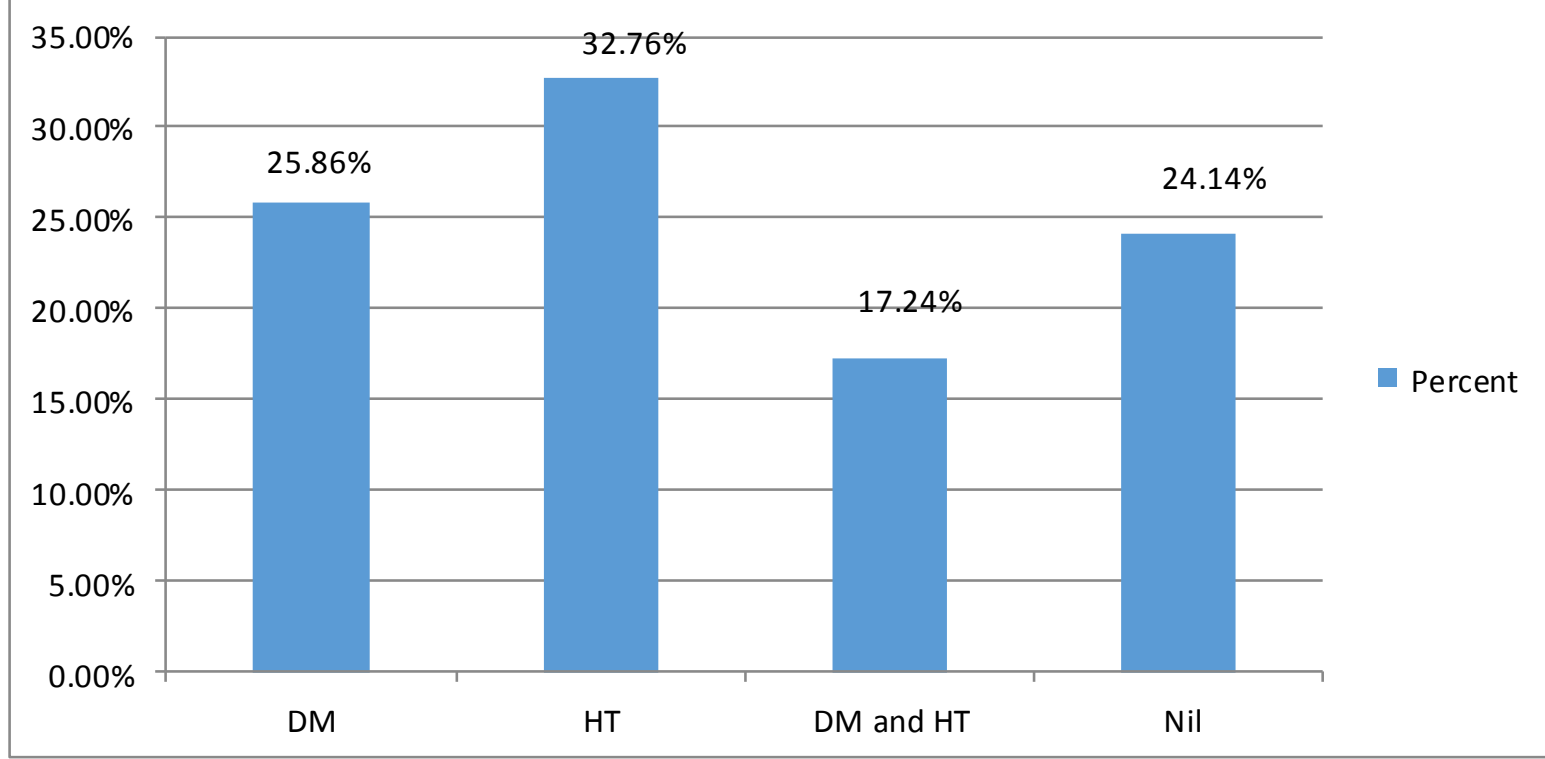


Fig.9 Monomicrobial and polymicrobial VAT

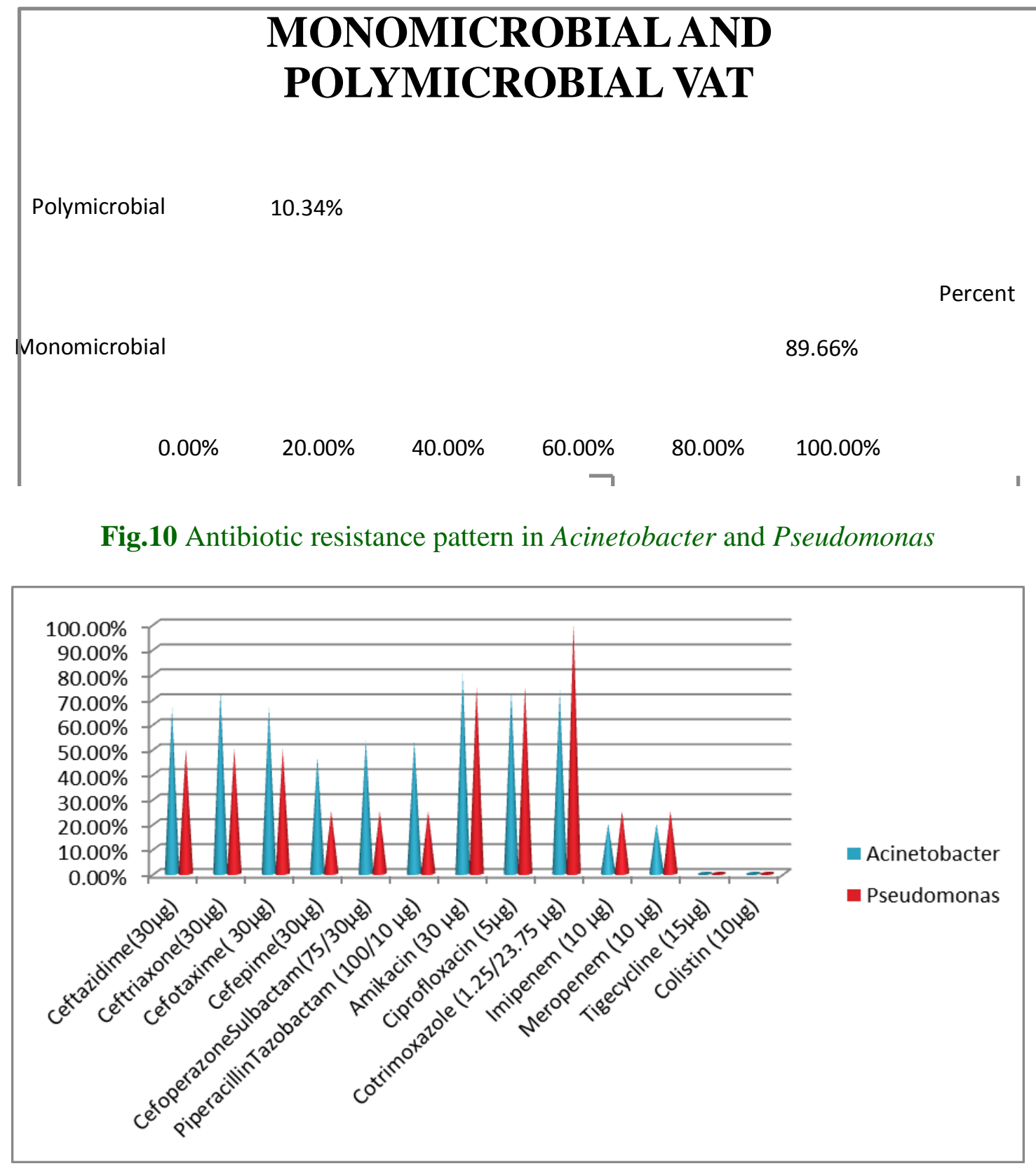

Table.1 Distribution of VAT patients by age group

\begin{tabular}{|l|c|c|c|}
\hline $\begin{array}{l}\text { AGE } \\
\text { GROUP }\end{array}$ & MALE & FEMALE & TOTAL \\
\hline $\mathbf{2 1 - 4 0}$ & 5 & 1 & $6(16.22 \%)$ \\
\hline $\mathbf{4 1 - 6 0}$ & 11 & 4 & $15(40.54 \%)$ \\
\hline $\mathbf{6 1 - 8 0}$ & 9 & 3 & $12(32.43 \%)$ \\
\hline $\mathbf{8 1 - 1 0 0}$ & 3 & 1 & $4(10.81 \%)$ \\
\hline
\end{tabular}


Int.J.Curr.Microbiol.App.Sci (2018) 7(4): 907-921

Table.2 Microbiological profile of VAT

\begin{tabular}{|l|l|c|c|}
\hline S.NO & ORGANISM & NUMIBR & PERCENT \\
\hline 1. & Acinetobacter baumannii & 15 & $33.33 \%$ \\
\hline 2. & Klebsiella pneumoniae & 10 & $22.22 \%$ \\
\hline 3. & Pseudomonas aeruginosa & 4 & $8.89 \%$ \\
\hline 4. & Staphylococcus aureus & 5 & $11.11 \%$ \\
\hline 5. & Escherichia coli & 2 & $4.44 \%$ \\
\hline 6. & Candida albicans & 6 & $13.33 \%$ \\
\hline 7. & Enterococcus & 1 & $2.22 \%$ \\
\hline 8. & Citrobacter & 1 & $2.22 \%$ \\
\hline 9. & Proteus & 1 & $2.22 \%$ \\
\hline
\end{tabular}

Table.3 Antibiotic resistance in gram positive bacteria

\begin{tabular}{|c|c|c|c|c|}
\hline \multirow{2}{*}{ Antibiotic disks } & \multicolumn{2}{|c|}{$\begin{array}{l}\text { Staphylococcus aureus } \\
\qquad(\mathrm{n}=\mathbf{5})\end{array}$} & \multicolumn{2}{|c|}{$\begin{array}{l}\text { Enterococcus } \\
\quad(\mathbf{n}=\mathbf{1})\end{array}$} \\
\hline & $\mathrm{S}$ & $\mathrm{R}$ & S & $\mathrm{R}$ \\
\hline Penicillin(10U) & 0 & $100 \%$ & NT & NT \\
\hline Ampicillin (10 $10 \mathrm{~g})$ & NT & NT & 0 & $100 \%$ \\
\hline Cefoxitin(30 $\mathbf{\mu g})$ & $40 \%$ & $60 \%$ & NT & NT \\
\hline Gentamicin(10 $\mu \mathrm{g})$ & $40 \%$ & $60 \%$ & NT & NT \\
\hline $\begin{array}{l}\text { High level } \\
\text { Gentamicin }\end{array}$ & NT & NT & $100 \%$ & 0 \\
\hline Erythromycin(15 $\mu \mathrm{g})$ & $40 \%$ & $60 \%$ & 0 & $100 \%$ \\
\hline Clindamycin $(2 \mu \mathrm{g})$ & $60 \%$ & $40 \%$ & NT & NT \\
\hline $\begin{array}{l}\text { Cotrimoxazole }(1.25 \\
/ 23.75 \mu \mathrm{g})\end{array}$ & $40 \%$ & $60 \%$ & NT & NT \\
\hline Ciprofloxacin(5 $\mu \mathrm{g})$ & $40 \%$ & $60 \%$ & 0 & $100 \%$ \\
\hline Linezolid(30 $\mu \mathrm{g})$ & $100 \%$ & 0 & $100 \%$ & 0 \\
\hline Teicoplanin $(30 \mu g)$ & $100 \%$ & 0 & $100 \%$ & 0 \\
\hline Vancomycin(30 & $100 \%$ & 0 & $100 \%$ & 0 \\
\hline
\end{tabular}


Int.J.Curr.Microbiol.App.Sci (2018) 7(4): 907-921

Table.4 Antibiotic resistance in gram negative bacteria

\begin{tabular}{|c|c|c|c|c|c|c|c|c|}
\hline \multirow[t]{2}{*}{ Antibiotic disks } & \multicolumn{2}{|c|}{$\begin{array}{l}\text { Escherichia } \\
\text { coli } \\
(\mathrm{n}=2)\end{array}$} & \multicolumn{2}{|c|}{$\begin{array}{c}\text { Klebsiella } \\
\text { pneumoniae } \\
(\mathrm{n}=10)\end{array}$} & \multicolumn{2}{|c|}{$\begin{array}{c}\text { Citrobacter } \\
\quad(\mathrm{n}=1)\end{array}$} & \multicolumn{2}{|c|}{$\begin{array}{c}\text { Proteus } \\
(\mathrm{n}=1)\end{array}$} \\
\hline & $S$ & $\mathrm{R}$ & $S$ & $\mathrm{R}$ & $S$ & $\mathrm{R}$ & $\mathrm{S}$ & $\mathrm{R}$ \\
\hline $\begin{array}{l}\text { Ampicillin } \\
(10 \mu g)\end{array}$ & 0 & $100 \%$ & NT & NT & 0 & $100 \%$ & 0 & $100 \%$ \\
\hline $\begin{array}{l}\text { Ceftazidime } \\
(30 \mu \mathrm{g})\end{array}$ & $50 \%$ & $50 \%$ & $60 \%$ & $40 \%$ & 0 & $100 \%$ & 0 & $100 \%$ \\
\hline $\begin{array}{l}\text { Ceftriaxone } \\
(30 \mu \mathrm{g})\end{array}$ & $50 \%$ & $50 \%$ & $60 \%$ & $40 \%$ & 0 & $100 \%$ & 0 & $100 \%$ \\
\hline $\begin{array}{l}\text { Cefotaxime } \\
(30 \mu g)\end{array}$ & $50 \%$ & $50 \%$ & $60 \%$ & $40 \%$ & 0 & $100 \%$ & 0 & $100 \%$ \\
\hline $\begin{array}{l}\text { Cefepime } \\
(30 \mu \mathrm{g})\end{array}$ & $100 \%$ & 0 & $80 \%$ & $20 \%$ & $100 \%$ & 0 & $100 \%$ & 0 \\
\hline $\begin{array}{l}\text { Cefoperazone } \\
\text { Sulbactum } \\
(75 / 30 \mu \mathrm{g})\end{array}$ & $100 \%$ & 0 & $80 \%$ & $20 \%$ & 0 & $100 \%$ & 0 & $100 \%$ \\
\hline $\begin{array}{l}\text { Amikacin } \\
(30 \mu \mathrm{g})\end{array}$ & 0 & $100 \%$ & $30 \%$ & $70 \%$ & 0 & $100 \%$ & 0 & $100 \%$ \\
\hline $\begin{array}{l}\text { Ciprofloxacin (5 } \\
\mu \mathrm{g})\end{array}$ & 0 & $100 \%$ & $50 \%$ & $50 \%$ & 0 & $100 \%$ & 0 & $100 \%$ \\
\hline $\begin{array}{l}\text { Cotrimoxazole } \\
(1.25 / 23.75 \mu \mathrm{g})\end{array}$ & 0 & $100 \%$ & $40 \%$ & $60 \%$ & 0 & $100 \%$ & 0 & $100 \%$ \\
\hline $\begin{array}{l}\text { Imipenem } \\
(10 \mu \mathrm{g})\end{array}$ & $50 \%$ & $50 \%$ & $80 \%$ & $20 \%$ & $100 \%$ & 0 & $100 \%$ & 0 \\
\hline $\begin{array}{l}\text { Meropenem } \\
(10 \mu \mathrm{g})\end{array}$ & $50 \%$ & $50 \%$ & $80 \%$ & $20 \%$ & $100 \%$ & 0 & $100 \%$ & 0 \\
\hline Tigecycline $(15 \mu g)$ & $100 \%$ & 0 & $100 \%$ & 0 & $100 \%$ & 0 & $100 \%$ & 0 \\
\hline Colistin $(10 \mu \mathrm{g})$ & $100 \%$ & 0 & $100 \%$ & 0 & $100 \%$ & 0 & NT & NT \\
\hline
\end{tabular}

Table.5 Comparison of incidence and gender distribution with other studies

\begin{tabular}{|l|l|c|c|c|c|}
\hline S. No & Author & $\begin{array}{c}\text { Incidence } \\
(\%)\end{array}$ & Males & Females & Reference \\
\hline 1. & Lei et al., & $15 \%$ & $73.5 \%$ & $26.5 \%$ & $(8)$ \\
\hline 2. & Ray et al., & $13.2 \%$ & $75 \%$ & $25 \%$ & $(9)$ \\
\hline 3. & Dallas et al., & $1.4 \%$ & $50 \%$ & $50 \%$ & $(10)$ \\
\hline 4. & Mayuri et al., & $16.7 \%$ & $69 \%$ & $31 \%$ & $(11)$ \\
\hline 5. & Present study & $24.83 \%$ & $75.68 \%$ & $24.32 \%$ & \\
\hline
\end{tabular}


Multidrug resistance (MDR) is defined as resistance to more than two groups of antibiotics (Magiorakos et al., 2012). $53.33 \%$ of Acinetobacter strains, $40 \%$ of Klebsiella pneumoniae, $75 \%$ of Pseudomonas aeruginosa, $100 \%$ of Escherichia coli, $100 \%$ of Citrobacter, $60 \%$ of Staphylococcus aureus were found to be multidrug resistant.

$66.67 \%$ of Acinetobacter isolates were resistant to Ceftazidime and Cefotaxime, $46.67 \%$ to Cefepime, $53.33 \%$ to Piperacillin Tazobactum and Cefoperazone Sulbactum, $80 \%$ to Aminkacin. Only $20 \%$ of the isolates were resistant to Carbapenems proving their effectivesness in VAT infections. All isolates were sensitive to Tigecycline and Colistin (Fig. 9).

$60 \%$ of Klebsiella pneumoniae isolates were resistant to Ceftazidime, Cefotaxime and Ceftriazone. $20 \%$ to Cefoperazone Sulbactum and Cefepime, Imipenem and Meropenem, $50 \%$ to Ciprofloxacin and $70 \%$ to Amikacin.

Among Pseudomonas aeruginosa, 50\% of isolates were resistant to Ceftazidime, Ceftriazone and Cefotaxime, $25 \%$ to Cefaperazone Sulbactum, $75 \%$ to Amikacin and Ciprofloxacin, $25 \%$ to Imipenem and Meropenem.

Among Escherichia coli isolates, 50\% were resistant to Cefotaxime and Ceftriaxone, 100 $\%$ to Amikacin and Ciprofloxacin, $50 \%$ to Imipenem and Meropenem. None of the isolates were resistant to Tigecycline and Colistin.

Among Staphylococcus aureus isolates, 60\% were MRSA, $60 \%$ resistant to Ciprofloxcin, Cotrimoxazole, Erythromycin and Gentamicin. All the isolates were sensitive to Linezolid and Vancomycin.

The increased prevalence of MDR infections were due to the increased use of fourth generation Cephalosporins in the ICU on admission.

Babu et al., in their study reported $24 \%$ of resistance in Amikacin, 96\% in Cefotaxime, $31 \%$ in Cefoperazone Sulbactum, 36\% in Cefpirome and $22 \%$ in Ciprofloxacin. Among Klebsiella isolates, 22\% in Amikacin, $61 \%$ in Cefoperazone Sulbactum, $43 \%$ in Ceftazidime, $20 \%$ in Ciprofloxacin. Among Pseudomonas aeruginosa isolates, $55 \%$ in Cefoperazone Sulbactum, $87 \%$ in Ceftazidime, $25 \%$ in Ciprofloxacin (Babu et al., 2011).

In a study by Ray et al., $100 \%$ of Acinetobacter baumannii and $33 \%$ of Pseudomonas aeruginosa were MDR.

Nseir et al., in their study reported 54\% VAT episodes were polymicrobial and $56 \%$ were related to multidrug-resistant bacteria (Nseir et al., 2005).

$78.7 \%$ isolates were multi drug resistant in a study by Mayuri (2017).

$20.35 \%$ of VAT cases were due to pan drug resistant isolates. Imipenem resistance of, $21.43 \%, \quad 33.3 \%$ and $44.82 \%$ among Pseudomonas aeruginosa, Klebsiella pneumoniae and Acinetobacter baumanii respectively was observed in a similar study (Babu et al., 2011).

Isolates were found to be pan resistant was reported by Álvarez Lerma et al., Fortunately there was no panresistant isolates in our study (Francisco Álvarez Lerma et al., 2017). In such cases Ceftalozane Tazobactum, a newly discovered Cephalosporin was found to be useful.

The mean days spent on mechanical ventilation was found to be $6.51 \pm 2.88$ days. 
The mean number of days spent in the ICU was found to be $8.76 \pm 7.68$ days. The mean hospital days were $14.78 \pm 9.92$ days.

The duration of mechanical ventilation for VAT patients was $21.6 \pm 16.0$ days and the length of ICU stay was $28.0 \pm 15.7$ days in a similar study (Nseir et al., 2005). In another study by Dallas et al., the duration of mechanical ventilation was $16.5 \pm 13.3$ days, ICU days $17.3 \pm 11.0$ and hospital days $26.6 \pm$ 16.7 days which is higher compared to our study (Dallas et al., 2011).

Babu et al., reported $12 \pm 2.1$ days hospital stay in VAT patients (Babu et al., 2011).

$18.92 \%$ of patients outcome ended in death and $37.84 \%$ of patients improved. The outcome of other VAT patients could not be assessed in our study because most of the patients got discharged at request at a critical condition. Nseir et al., observed a mortality of $55 \%$ and Dallas et al., 20\% (Nseir et al., 2002; Dallas et al., 2011).

VAT caused by MDR pathogens continues to be a threat to the hospital environment. It is associated with increased mortality, increased duration of mechanical ventilation, ICU stay in the hospital (Keyt et al., 2014).

A proper ventilator care bundle should be implemented. Proper weaning measures, sedation holidays should be done to reduce the duration of patients on mechanical ventilation (Shahabi et al., 2016).

A strict antibiotic policy should be framed and adhered to strictly to cut down the rate of multi drug resistance. Inhaled antibiotics can be given to reduce the risk of ventilator associated respiratory infections (Palmer et al., 2008). More research should be done in the future to know the local resistance patterns of the isolates causing ventilator associated respiratory infections.

\section{References}

Babu K. V. Y, Jayasimha V. L, Basavarajappa K. G, Kumar A, Kumar K. G. R, Niranjan H. P, Vijayanath V. A Comparative Study of Ventilator-Associated Pneumonia and Ventilator Associated Tracheobronchitis: Incidence, Outcome, Risk Factors. Biosci Biotech Res Asia 2011; 8(1)

Craven DE, Hudcova J, Lei Y, Craven KA, Waqas A. Pre-emptive antibiotic therapy to reduce ventilator-associated pneumonia: "thinking outside the box." Critical Care. 2016; 20:300. doi:10.1186/s13054-016-14725.

Craven DE. Ventilator-associated tracheobronchitis (VAT): questions, answers, and a new paradigm? Critical Care. 2008; 12(3):157.

Dallas J, Skrupky L, Abebe N, Boyle WA $3^{\text {rd }}$, K1ollef $\mathrm{MH}$. Ventilator-associated tracheobronchitis in a mixed surgical and medical ICU population. Chest 2011; 139:513-8.

Francisco Álvarez Lerma, Rosana Muñoz Bermudez, Santiago Grau, María Pilar Gracia, Arnillas,Luisa Sorli, Lluis Recasens, Miquel Mico García, Ceftolozane-tazobactam for the treatment of ventilator-associated infections by colistin-resistant Pseudomonas aeruginosa. Rev Esp Quimioter 2017; 30(3): 224-228

Hashemi SH, Hashemi N, Esna-Ashari F, Taher A, Dehghan A. Clinical Features and Antimicrobial Resistance of Bacterial Agents of Ventilator-Associated Tracheobronchitis in Hamedan, Iran. Oman Medical Journal. 2017; 32(5):403-408.

Karvouniaris M, Makris D, Manoulakas E, Zygoulis P, Mantzarlis K, Triantaris A, Chatzi M, ZakynthinosE. VentilatorAssociated Tracheobronchitis Increases the Length of Intensive Care Unit Stay. Journal of Infection control and hospital epidemiology August 2013; 34(8): 800-808

Keyt, H, Faverio P, Restrepo MI. Prevention of ventilator associated pneumonia in the intensive care unit: A review of the clinically 
relevant recent advancements. Indian $\mathrm{J}$ Med Res. 2014 Jun; 139(6):814-821.

Lei, Y., Hudcova, J., Rashid, J., Sarwar, A., Gillespie, W., Finn, C., Goggin, M., Omran, M., Boroda, E. and Craven, D. (2016) Natural History, Outcomes and Antibiotic Treatment for Ventilator-Associated Tracheobronchitis in Critical Ill Patients. Modern Research in Inflammation, 5, 1-11. doi: 10.4236/mri.2016.51001.

Magiorakos AP, Srinivasan A, Carey RB, Carmeli Y, Falagas ME, Giske CG, Harbarth S, Hindler JF, Kahlmeter G, Olsson-Liljequist B, Paterson DL, Rice LB, Stelling J, Struelens MJ, Vatopoulos A, Weber JT, Monnet DL. Multidrug-resistant, extensively drug-resistant and pandrug-resistant bacteria: an international expert proposal for interim standard definitions for acquired resistance. Clin Microbiol Infect. 2012 Mar; 18(3):26881.

Manchanda V, Sanchaita S, Singh N. Multidrug Resistant Acinetobacter. Journal of Global Infectious Diseases. 2010; 2(3):291-304.

Martin-Loeches I, and Pobo A. What is new in ventilator-associated tracheobronchitis? Clin Pulm Med. 2010; 17(3):117-121.

Martin-Loeches, I., · S. Nseir · J. Valles · A. Artigas. From ventilator-associated tracheobronchitis to ventilator-associated Pneumonia. Réanimation (2013) 22:231-237

Mayuri, K.S. 2017. Ventilator Associated Tracheobronchitis: Incidence, Etiology, Predisposing Risk Factors and Drug Resistance. Int.J.Curr.Microbiol.App.Sci.6(7): 3864-387

Nseir S, and Martin-Loeches I. Ventilatorassociated tracheobronchitis: where are we now? Revista Brasileira de Terapia Intensiva. 2014; 26(3): 212-214. doi:10.5935/0103507X.20140033.

Nseir S, Di Pompeo C, Soubrie S, Lenci H, Delour P, OnimusT, Saulnier F, Mathieu D,
Durocher A.Effect of ventilator-associated tracheobronchitis on outcome in patients without chronic respiratory failure: a casecontrol study. Critical Care 2005, 9:R238R245 (DOI 10.1186/cc3508)

Nseir S, Di Pompeo C, Pronnier P, et al., Nosocomial tracheobronchitis in mechanically ventilated patients: incidence, aetiology and outcome. Eur Respir J 2002; 20:1483-1489.

Palmer LB, Smaldone GC, Chen JJ, Baram D, Duan T, Monteforte M, Varela M, Tempone AK, O'Riordan T, Daroowalla F, Richman P. Aerosolized antibiotics and ventilatorassociated tracheobronchitis in the intensive care unit. Crit Care Med. 2008 Jul; 36(7): 2008-13.

Ray U, Ramasubban S, Chakravarty C, Goswami L, Dutta S. A prospective study of ventilatorassociated tracheobronchitis: Incidence and etiology in intensive care unit of a tertiary care hospital. Lung India 2017; 34:236-40

Saad Nseir, Raphaël Favory, Elsa Jozefowicz, Franck Decamps, Florent Dewavrin, Guillaume Brunin, Christophe Di Pompeo, Daniel Mathieu, Alain Durocher and the VAT Study Group. Antimicrobial treatment for ventilator-associated tracheobronchitis: a randomized, controlled, multicenter study. Critical Care 2008 12:R62

Sadek S, El-Said A, Madkour A, Rabie A, Maky Y. Ventilator-associated tracheobronchitis in a surgical ICU population. Egypt J Bronchol 2014; 8:153-9

Shahabi M, Yousefi H, Reza Yazdannik A, Alikiaii B. The effect of daily sedation interruption protocol on early incidence of ventilator associated pneumonia among patients hospitalized in critical care units receiving mechanical ventilation. Iran J Nurs Midwifery Res. 2016 Sep-Oct; 21(5):541-546.

\section{How to cite this article:}

Nanthini Devi, P. and Gomathi, S. 2018. A Study of Incidence and Microbiological Profile of Ventilator Associated Tracheobronchitis (VAT) in a Tertiary Care Hospital. Int.J.Curr.Microbiol.App.Sci. 7(04): 907-921. doi: https://doi.org/10.20546/ijcmas.2018.704.097 